\section{COMMUNITY ENERGY SYSTEMS \\ AND THE LAW OF PUBLIC UTILITIES

\begin{tabular}{c} 
Volume Forty-Seven \\
VERMONT \\
\hline
\end{tabular}

Final Report of

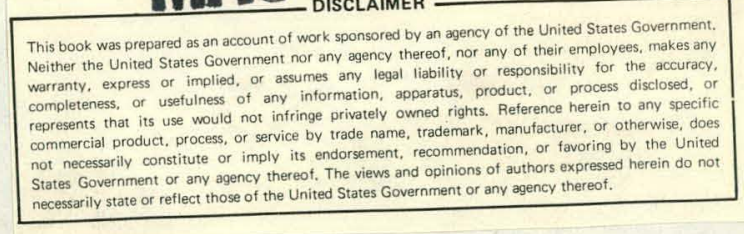

A Study of the Impacts of Regulations
Affecting the Acceptance of
Integrated Community Energy Systems
DUANE A. FEURER CLIFFORD L. WEAVER
Program Managers

\begin{abstract}
KEVIN J. RIELLEY KEVIN C. GALLAGHER
SUSAN B. HARMON DAVID T. HEJNA
\end{abstract}

Professor Edmund W. Kitch, Consultant

January, 1981

ROSS, HARDIES, O'KEEFE, BABCOCK \& PARSONS

One IBM Plaza, suite 3100

Chicago, Illinois 60611

Telephone: (312) 467-9300

\author{
Prepared For \\ UNITED STATES DEPARTMENT OF ENERGY \\ Division of Buildings and Community Systems \\ under Contract No. DE-AC02-78CS20289
}

This report was prepared as an account of work sponsored by an agency of the United States Government. Neither the United states nor any agency thereof, nor any of their employees, makes any warranty, expressed or implied, or assumes any legal liability or responsibility for any third party's use or the results of such use of any information, apparatus, product, or process disclosed in this report, or represents that its use by such third party would not infringe privately owned rights. 


\section{DISCLAIMER}

This report was prepared as an account of work sponsored by an agency of the United States Government. Neither the United States Government nor any agency Thereof, nor any of their employees, makes any warranty, express or implied, or assumes any legal liability or responsibility for the accuracy, completeness, or usefulness of any information, apparatus, product, or process disclosed, or represents that its use would not infringe privately owned rights. Reference herein to any specific commercial product, process, or service by trade name, trademark, manufacturer, or otherwise does not necessarily constitute or imply its endorsement, recommendation, or favoring by the United States Government or any agency thereof. The views and opinions of authors expressed herein do not necessarily state or reflect those of the United States Government or any agency thereof. 


\section{DISCLAIMER}

Portions of this document may be illegible in electronic image products. Images are produced from the best available original document. 
ABSTRACT

PREFACE

ACKNOWLEDGEMENTS $\therefore$

CHAPTER 1: EXECUTIVE SUMMARY .

CHAPTER 2: REGULATION OF PUBLIC UTILITIES * • • • • • • • • . 8 Footnotes . . . . . . . . . . . . . . 15

CHAPTER 3: SITING OF ENERGY FACILITIES . • . • . . • • • • . . 17 Footnotes . . . . . . . . . . . . . . . . . . 29

CHAPTER 4 : FRANCHISING OF PUBLIC UTILITIES . • . . . • • • • • • 31

Footnotes . . . . . . . . . . . . . . . . 34

CHAPTER 5: REGULATION OF PUBLIC UTILITY RATES. . . • • • • . 35

Footnotes . . . . . . . . . . . 56

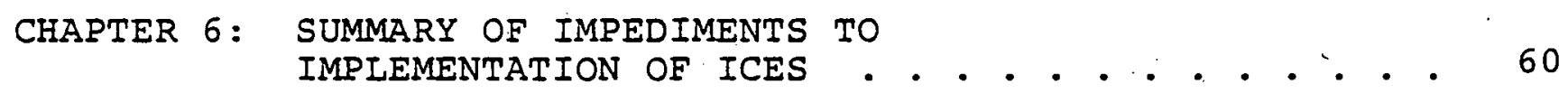

CHAPTER 7: OVERCOMING IMPEDIMENTS TO

ICES -- A SUMMARY . . . . . . . . . . . . . . . . 


\section{ABSTRACT}

This report contains a detailed description of the Iaws and programs of the state of vermont governing the regulation of pubiic energy utilities, the siting of energy generating and transmission facilities, the municipal franchising of - public energy utilities, and the prescription of rates to be charged by utilities including attendant problems of cost allocations, rate base and operating expense determinations and rate of return allowances. These laws and programs are analyzed to identify impediments which they may present to the implementation of Integrated Community Energy Systems (ICES). This report is one of fifty-one separate volumes which describe such regulatory, programs at the federal level and in each state as background to the report entitled "Community Energy systems and the and the Law of Public Utilities -- Volume One: An overview." This report also contains a summary of a strategy described in Volume one -- An overview for overcoming these impediments by working within the existing regulatory framework and by making changes in the regulatory programs to enhance the likelihood of ICES implementation. 


\section{PREFACE}

one resconse to current concerns about the adequacy of the nation's energy supplies, in addition to reducing consumption of energy, is to make more efficient use of existing energy resources. The united States Department of Energy (DOE) has Funded research, development and demonstration programs to determine the feasibility of applying proven cogeneration technologies in centralized energy systems, known as Integrated Community Energy systems (ICES), to provide heating, cooling and electrical services to entire communities in an energy conserving and economic manner.

The relevant "community" which will be appropriate for ICES development will typically consist of a combination of existing or potential energy "wasters" -- i.e, installations with large energy conversion facilities'which, when operated in a conventional manner, exhaust usable'amounts of waste heat or mechanical energy -- and existing and potential energy users -i.e., industrial, commercial, institutional or residential structures which obtain electricity and gas from a traditional central utility and convert part of it on site to space heating and cooling purposes.

In most current applications, energy conversion fac1l1ties burn fuels such as coal, oil or natural gas to produce a 
single energy stream such as process steam or electricity for various industrial processes or for sale to other parties. In the conversion process, substantial amounts of energy may be wasted. For example, it has been estimated that from 60 to 75 percent of the potential energy available in fuel burned to generate electricity is lost in the process of generating and delivering the electririty:

The technology exists, however, to produce and utilizo more than one energy stream from most energy conversion processes so that the input of a given amount of fuel could lead to the production of far more usable energy than is generally true in most steam production processes. This technology is the foundation of the ICES concept. Current examples of the technology can be found on university campuses, industrial or hospital comploxes and other developments where a central power plant provides not only olectricity but also thermal energy to the relevant community.

It is generally assumed by DOE that ICES will be designed to produce sufficient thermal energy to meet all the demands of their communities and that they will be interconnected with existing electric utility grids. Through such an interconnection, an ICES would be able to purchase elertricity when ite community's need for electricity exceeds the amount which could be produced from the level of operations needed to meet the community's thermal needs. In addition, when operations to meet thermal needs result in generation of more electricity than 
necessary for the ICES community, the ICES would be able to seil excess electricity to the grid.

ICES may take a variety of forms, from a single owneruser, such as a large industrial complex or university campus, where all energy generated is used by the owner without sales to. other customers, to a iange residential community in which central power plant produces heat and electricity which is sold at retail to residents of the community. Since successful operation of an ICES presupposes that the ICES will be able to use or sell all energy produced, it can be anticipated that all ICES will at some point seek to sell energy to customers or to the electric utility grid from which the electricity will be sold to customers. By their very nature ICES are likely to be classified as public. utilities under the laws of many, or even all, states.

Ross, Hardies, O'Keefe, Babcock \& Parsons has undertaken a contract with the Department of Energy to identify impediments to the implementation of the ICEs, concept found in existing institutional structures established to regulate the construction and operation of public utilities. These institutional structures have been developed in light of policy decisions which have determined that the most effective means of providing utility services to the public is by means of regulated monopolies serving areas large enough to permit exploitation of economies of scale while avoiding wasteful duplication of production and delivery facilities. These existing institutional structures have led to an 
energy delivery system characterized by the construction and operation of large central power plants, in many cases some distance from the erincipal popuiation centers being served.

In contrast, effective implementation of ICES depends to some extent upon the concept of small scale operations supplying a Iimited market in an area which may be served by other suppliers of utility services. ICEs may in many instances involve both existing regulated utilities and a variety of non-utility energy producers and consumers who have not traditionally been subject to public utility type regulation. Implementation of the ICES concept will also require a variety of non-traditional relationships between existing regulated utilities and non-regulated energy producers and consumers.

The purpose of this report is to generally describe the existing scheme of public utility regulation as it is likely to relate to the development and operation of an ICES, the construction of ICES facilities and the determination of relevant cost of service, rate of return and rate structure for the sale and pur* chase of energy by an ICES. Attention is given to the problems of the entry of an ICES into an energy market which has traditionaliy been characterized by a form of regulated monopoly where only one utility has been authorized to provide a particular service in a given area. 
This report is one of a series of reports covering the law of each of the 50 states and the federal government and should be read in conjunction with volume one in this series entitlea Community Energy Systems and the Law of Public Utilities: An Overvisiv. That volume provides a national overview of the regulatory programs described in detail for the particular state covered by this report. It also provides an analysis of the impediments to effective implementation of the ICES concept and a series of recommendations for responding to those impediments. In many juriscictions legal issues similar to those likely to arise in the implementation of the ICES concept have not previously been faced. Thus, this series of reports cannot give definitive guidance as to what all of the anșwers are'with respect to all issues which may face ICES implementation. However, by having an understanding of the issues which may arise in the course of an effort to implement ICES, an ICES developer will be better equipped to seek solutions.

Ross, Hardies, O'Keefe, Babcock \& Parsons has been assisted in this study by Professor Edmund Kitch, Professor of Law at the University of Chicago Law School; Deloitte, Haskins \& Sells, independent public accountants; and Hittman Associates, Inc., engineering consultants. 


\section{ACKNOWLEDGEMENTS}

ile wish to acknowledge the efforts of numerous individuals who have assisted in the preparation of the series of reports which make up the study of the Impacts of Regulations Affecting the Acceptance of ICES. A number of lawyers and paralegal personnel of Ross, Hardies, have assisted in the research, writing, critiquing, rewriting, proofreading and other efforts including Drew Kaplan; Iinda Arbetman; Cheryl K. Hachman; Barbara L. Ross; Joel F. Bonder; Sally H. Newton; Susan N. Stearns; Richard F. Babcock; Donald W. Glaves; Theda C. Snyder; Patricia J. Crowe; Susan E. Merritt; Eileen A. Müench; Elizabeth West; Catherine B. Lipscomb; Margaret R. Hessler; and Elizabeth Walter.

Preparation of reports covering regulatory programs in every state has taken considerable research effort and we are grateful to a group of law students who spent not only countless hours in libraries, but also a great deal of time on telephones contacting public officials around the country to secure information about utility regulatory programs. Among the students were Marchall Seeder; Carl Anderson; Locke E. Bowman, III; James G. Bullard; Bruce W. Dewald; Norman B. Julius; Bruce S. Klafter; Ruth B. Rleiman; Suzanne Metzel; Terrence J. Molinari; Alison Moss; Rose M. Urban; Garth D. Wilson; Iinda Yi; Shell Bleiweiss and Neal Heriaud. 
We would also like to acknowledge the contributions of subcontractors Hittman Associates, Inc. and Deloitte, Haskins \& Sells, Inc. who have assisted us in an appreciation of some of the engineering and pubitc utility accounting and ratemaking aspects of this project. 
-viii-

Blank 


\section{CHAPTER 1}

\section{EXECUTIVE SUMMARY}

\section{REGUIATION OE DUBIIC UTIIITIES}

The authority to regulate public utilities in Vermont is vested in the Vermont Public Service Board (PSB), which is comprised of Enree members appointed by the governor, with the advice and consent of the senate, to serve for terms of six years. Local governments retain little authority. Although local governments do regulate the use of streets and other public property, their decisions can be appealed to the PSB, the decisions of which are final.

The PSB exercises regulatory authority over companies engaged in the manufacture and sale of gas or electricity for use by the public for lighting, heating, or power or for use associated with the public highways. Companies are defined to include individuals, corporations, associations, partnerships and municipalities. The PSB also regulates companies other than municipalities engaged in the collection and sale of water for domestic or industrial purposes. Electric cooperatives are exempt from PSB jurisdiction.

The PSB has jurisdiction over both direct and indirect sales to the public. Production for private use is exempt from regulation. Similarly, furnishing energy for one's tenants is a private use, and therefore, outside of PSB jurisdiction. 
The PSB, by statute, is empowered to set rates, approve issuances of securities, prescribe a system of accounts, approve mergers and consolidations, approve sales and leases of property, permit construction and order extensions. The PSB can also order one electric company to sell energy to another.

Prior to incorporating as a public utility, a corporation must obtain a certificate stating that its establishment will promote the general good of the state. A similar certificate is required prior to instituting service or commencing construction. Any extensions of service which entail construction of a new facility will require a certificate. The PSB is authorized to establish exclusive service areas to be served by electric utilities.

After an application for a certificate is filed with PSB, a public hearing is required. The only criterion established for granting a certificate is that the operations will promote the general good of the state. A utility company must obtain prior approval of the PSB in order to abandon any part of its facilities. The PSB has authority to resolve service area disputes. Any party aggrieved by a final judgment of the PSB may appeal directly to the state supreme court. Review of the Commission's decision is on the record.

II. SITING OF ENERGY FACILITIES

Two separate boards are involved in siting energy facilities. The PSB derives its authority over new electric generation and transmission facilities from Title 30 , section 248 of the Vermont statutes. The Environmental Board, a nine 
person board appointed by the governor, with the senate's consent, derives its authority over developments involving certain minimum acreages from Act 250 of 1969. The term "development", for the purposes of determining the authority of the Environmental Board, covers energy facilities not covered by section 248 . The siting authority of the PSB and the Environmental Board is not preemptive of the authority of other state agencies. For example, three of the departments of the Environmental conservation Agency require permits for construction. Local development plans must be followed in the Act 250 permitting process, but not in issuing Section 248 certificates.

Section 248 prohibits any company or cooperative from beginning site preparation or construction of an electric generation or transmission facility unless the PSB certifies that the project will promote the general good of the state. Act 250 requires that a permit be obtained for any subdivision or development.

A party seeking a certificate under section 248 must file a petition with the PSB. An applicant for a permit under Act 250 must file with the appropriate District Environmental Commission. Both boards are required to hold hearings and provide adequate notice. Judicial review of PSB decisions is available upon direct appeal to the state supreme court, with review made on the record. An appeal to the Environmental Board can be removed to the superior court, with further appeal available to the state supreme court. Findings at the board or superior 
court levels are held to be conclusive.

Section 243 sets forth four criteria for the issuance of a permit: (1) that construction will not unduly interEere with the orderly development of the region; (2) that construction is necessary to meet the present and future need of the area; (3) that there will be no adverse systemic or economic impacts; and (4) that there will he no adverse impact on the environment or inhabitants. Act 250 sets forth the following nine criteria: (1) potential for pollution; (2) availability of water; (3) burden on water supply; (4) possibility of soil erosion; (5) potential for congestion; (6) burden on the municipality; (7) environmental effects; (8) conformity with the development plan; and (9) conformity with the regional plan.

The permit criteria in section 248 and Act 250 apply to all facilities or developments subject to their respective jurisdictional provisions. III. FRANCHISING OF PUBLIC UTILITIES

Neither the state's constitution nor its statutes vest any public body with authority to grant franchises for the use of public streets and places in connection with providing utility service. Franchising authority has been found by the courts to reside with the municipalities. Franchise application procedures thus differ with each individual municipal charter and ordinance. No reported decisions discuss the criteria to be considered in granting a franchise. 
the discretion of the state legislature in granting charters ard local governments in enacting ordinances. However, the Vermont supreme Court has held that a holder of a certificate neec not obtain local approval before constructing a facility, ano thus, local Eranchising law is largely insignificant with respect to public utilities. IV. UTILITY RATE REGULATION

The statutes of Vermont vest the authority to regulate rates of public utilitie's in the PSB, Cooperatives, investorowned and publicly-owned utilities are subject to rate regulation by the PSB, Municipalities may not approve or prescribe rates of utilities. Vermont has adopted the NARUC system of accounts for gas utilities and the FERC system of accounts for electric utilities.

The statutes provide that the PSB may order an investigation and hearing into a proposed rate change. The PSB may order that a proposed change not take effect until final determination of the hearing, in which case the PSB must proceed as quickly as possible and make a determination within six months. If the PSB does not make a determination within six months, the utility may put the proposed rates into effect upon filing a bond with the PSB to refund to its customers the difference between the rate charged and the rate finally authorized.

In determining a utility's rate base, the PSB uses a historical average test period and an original cost less depreciation method of valuation. The PSB has held that rate base should 
only reflect that portion of plant attributable to regulated utility service. Historically, the PSB has excluded construction work in progress from rate base, although it has been included for minor facilities constructed over a short period of time. The PSB has also included "property held for future use" in rate base in some instances.

The PSB has approved a company'g use of a peak responsibility method to assign rate,base between jurisdictional retail and non-jurisdictional wholesale customers.

The general test for inclusion of expenses in the cost of service appears to be the reasonableness of the actual costs incurred in the rendition of utility service. The PSB has indicated its approval of the inclusion of research and development expenses in the cost of service. The PSB has also approved of the allocation of expenses to utility and nonutility operations using the percentages of total sales attributable to each operation.

In a recent rate case, the PSB allower a filowthrough of liberalized depreciation. Similar treatment has recently been applied to the investment tax credit.

The PSB does not use a particular method or combination of methods to establish an authorized return on equity. The PSB has, however, attached special significance to comparable earnings studies. The PSB uses expert studies merely as guidelines, ensuring flexibility to account for various factors in arriving at a return on equity. 
taken by the PSB in setting rates to various customer classes. The PSB wili, nowever, consider other factors such as value of service when appropriate. Lifeline rates are not statutorily mandated.

The $P S B$ is granted the authority to control the issuance of securities. The statutes provide that no issuance shall be made if inconsistent with the public good. 


\section{CHAPTER 2}

\section{REGULATION OF PUBLIC UTILITIES IN VERMONT}

\section{AGENCIES WHICH REGULATE PUBLIC UTILITIES}

The authority to regulate public utilities is vested generally in the Vermont Public Service Board (PSB). The PSB is comprised of a chairman and two members, who shall be nominated, appointed and confirmed in the manner of a superior judge. PSB members serve six year terms. $1 /$ Members must be free from any employment or pecuniary interests in any company subject to the supervision of the PSB.

Local governments retain little regulatory authority over public utilities. Local governments are responsible for regulating the use of streets and other public property, $\underline{3 /}$ but any person aggrieved by a local decision may appeal to the PSB within thirty days. ${ }^{\prime}$ The PSB is to review the local action at a public hearing and its decision is final.

II. JURISDICTION OF THE BOARD

The PSB jurisdiction extends to the following:

(i) A company engaged in the manufacture, transmission distribution or sale of gas or electricity directly to the public or to be used ultimately by the public for lighting, heating or power and so far as relates to their use or occupancy of the public highways;

(2) That part of the business of a company which consists of the manufacture, transmission, distribution or sale of gas or electricity directly to the public or to be used ultimately by the public for lighting, heating or power and so far as relates to their use or occupancy of the public highways; 
(3) A company other than a municipality engaged in the collecting, sale and distribution of water for conestic, industrial, business or fire protection purposes; $6 /$

The specific activities subject to the PSB's control are identitied in the jurisdictional provision. The PSB may regulate the "manuiacture, transmission, distribution or sale ard distribution" of gas and electricity and the "collection, sale and distribution" of water.

The PSE has jurisdiction over "companies" which are defined to incluose individuals, partnerships, associations, corporations anc maicipalities. ${ }^{7 /}$ This provision is broad enough to extend tre PSB's jurisdiction to most conventional : forms of utility ownership. However, electric cooperatives generally are exempt from the jurisdiction and control of the PSB. $8 /$

The PSB is empowered to regulate companies which furnish gas or electricity "directly to the public or to be used ultimately by the public." $9 /$ Thus, the PSB has jurisdiction over both direct and indirect sales.

The PSB's jurisdiction is dependent upon furnishing services directly or indirectly to the public. $\frac{10 /}{}$ while there is no statutory definition of public, the Vermont Supreme Court has considered this issue. In Valcour v. Village of Morrisville, ${ }^{11 /}$ the court considered the question of whether a municipally-owned electric company was a public utility with respect to its operations outside of the corporate 
limits. The defendant municipality owned an electric plant which it used to provide service to its residents, surpius electricity was sold by contract to numerous customers outside of the corporate limits. The plaintiff, a resident of another municipality, filed suit to force the utility to restore his service.

The court held that the utility could not be forced to serve the plaintiff because it was not a public utility with respect to its extra-municipal operations. The court reasoned that the status of the utility was:

that of a purveyor of electric energy by special contract, and its transmission lines and equipment used for that purpose are not dedicated to public use. If it has not professed to sell to the public indiscriminately at regular rates, which is the fundamental characteristic of a public calling, but has adopted the policy of entering into special contracts on its own terms, it is engaged in private business. Wyman, Public Service Corporation, $\$ \$ 227,243$. Its contracts are of interest or concern only to the immediate parties, and are purely voluntary; and there is no right to compel the sale of its surplus. 12/

While there are no specific statutory exemptions for the production, generation or storage of energy for private use or for the use of tenants, clearly production for private use would be exempt as not involving servicc provided directly or indirectly to the public. Similarly, the furnishing of energy for one's tenants should, under the rationale of Valcour be considered a private use and, therefore, not within the PSB's jurisdiction. 
III. POWERS OF PSB

The PSB is charged with the general supervision of $13 /$

jurisdictional utilities.

In adition to this general

power, the PSB has been granted a variety of specific powers. These powers include authority to set the rates for sales to the publici ${ }^{14 /}$ approve the issuance of securities; $\stackrel{15 /}{\text { pre- }}$ scribe a system of accounts; ${ }^{16 /}$ approve the merger or con-

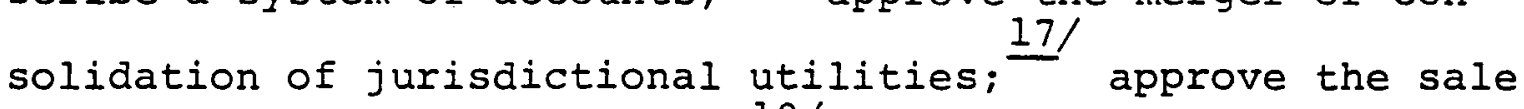
or lease of utility property; $\stackrel{18 /}{ }$ permit construction of a new electric generation or transmission facility; $\stackrel{19 /}{\text { and order }}$ extension of service to new customers. In addition, the. PSB is authorized, upon petition, to order an electric company to sell energy to, to exchange energy with, or to transmit or distribute energy to another electric company. Such an order can be issued so long as the respondent electric company's ability to serve its customers would not be impaired. $21 /$

IV. AUTHORITY TO ASSIGN RIGHTS TO PROVIDE SERVICE IN A GIVEN AREA

A. Generàlly

A corporation which proposes to incorporate in Vermont to operate as a public utility, must obtain a certificate stating its establishment will promote the general good of the state. $\frac{22 /}{A}$ certificate is also required before 
a company may institute service to the public $\frac{23 /}{4}$ or before new electric generation or transmission facilities are constructed. $24 /$ Replacement of existing electric facilities does not require a certificate.

The PSB may authorize the extension of electric service to a person or property not presently served. Such an extension can also be made without PSB approval if the area to be served is closer to the utility's service lines than the lines of any other public utility, or with the consent of the other public utility. $25 /$ Any extension which entails constructing a new electric facility will require a certificate of public good. $26 /$

\section{B. Competition}

The PSB is authnrizen to establish exclusivo service areas to be served by electric utilities. $27 /$ In establishing these service areas, the PSB is to consider existing service, voluntary agreements among utilities, consistency with the orderly development of the area, natural geographic boundaries, and compatibility with the interest of all consumers and all other relevant factors. $28 /$ The PSB is not specifically authorized to assign exclusive service areas to other jurisdictional utilities and no reported agency or judicial decisions have considered the issue of competition among utilities. 


\section{Certificating Proceiures}

The process of cbtaining a certificate to begin operating a utility is initisted by petitioning the FSB to hold a public hearing in the county where the proposed utility is to operate. The DSE vill set a time and place for hearing the petition and will publish the substance of the petition and notice of the hearing in a county newspaper. The procedure for obtaining a certificate to construct new electric facilities is discussed in Chapter $3, \overline{P a r t}$ III. The only criterion established for granting a certificate to commence operations is that the operations will promote the general good of the state. $30 /$ The criteria governing the granting of certificates to construct new electric facilities are discussed in Chapter 3, Part IV.

A public utility company may not abandon any service subject to the PSB's jurisdiction, or abandon any part of its facilities, without first obtaining approval of the PSB. $31 /$ Abandonment of service will be permitted if, after notice and hearing, the PSB finds that the curtailment or abandonment is consistent with the public interest.

D. Service Area Disputes

The PSB has been given specific authority to resolve service area disputes between electric utilities. Such disputes will be resolved by the PSB after notice to all interested parties and a hearing. Service area disputes 
involving other public utilities may be resolved by the PSB pursuant to its general procedure for hearing complaints. Ary person may complain that a public utility has acted unlawfully. 34

i. APPEALS OF REGULATORY IECISIONS

Any party aggrieved by a final juagment of the PSB may appeal directly to the state supreme court. Aggricved porsons arc not rcquired to such rehering hefore the PSB before seeking review in the supreme court. The appeal must be filed within thirty days of entry of jugement by the PSB. $36 /$ The review by the supreme court is based on the record of the proceeding before the PSB. 


\section{FOOTNOTES}

1. vt. Stat, Ann. tit. 30, $\$ 3($ a) (Equity Supp. 1980).

2. Id. $\$ 4$.

3. Id. $\$ 2504$ (Equity 1970).

4. Id. $\$ 223$.

5. Ibid.

6. Id. $\$ 203$ (Equity Supp. 1980).

7. Id. $\$ 201$.

8. Id. $\$ 3039$ (Equity 1970).

9. Id. $\$ 203(1)$ (Equity Supp. 1980).

10. Ibid.

11. Valcour V. Village of Morrisville, $108 \mathrm{Vt} .242,184$ A.881 (1938).

12. Id. 184 A. at 885 .

13. Vt. Stat. Ann. tit. 30, $\$ 203$ (Equity Supp. 1980).

14. Id. $\$ \$ 209(4), 2801$ (Equity Supp. 1980).

15. Id. $\$ \$ 108(a), 209(7)$ (Equity Supp. 1980).

16. Id. 221 (Equity 1970).

17. Id. 109 (Equily 1970).

18. Id. $\$ \$ 109,232$.

19. Id. $\$ 248$ (Equity Supp. 1980).

20. Id. $\$ 2809$ (Equity 1970).

21. Id. $\$ 214$.

22. Id. \$102. (Equity Supp. 1980).

23. Id. $\$ 231$. 
24. Id. $\$ 248$.

25. Id. \$2809 (Equity 1970).

26. Id. $\$ 248$ (Equity Supp. 1980).

27. Id. $\$ 249$.

29. Ibid.

29. Id. $\$ 231(a)$

30. Ibid.

31. Id. $\$ 231(\mathrm{~b})$.

32. Ibid.

33. Id. \$2810 (Equity 1970).

34. Id. \$208 (Equity Supp. 1980).

35. Id. $\$ 12$ (Equity Supp. 1980).

36. Id. tit. 12, $\$ 2383$ (Equity 1973).

37. Rule of App. Pro. $13(d)$. 


\section{CHAPTER 3}

\section{SITING OF ENERGY FISTIITIES TN TERMONT}

\section{PURLIC AGENCIES WHICH ADMINISTER SITING EANS}

There are two statutes in Vermont which directly

govern the siting of energy facilities. As discussed in

Chapter 2, the Public Service Bcard (PSB) is responsible for

certifying new electric generation and transmission facilities.

The Environmental Board, which is a part of the Vermont

Environmental Conservation Agency, Iicenses developments

involving certain minimum acreages, including any electric

generation or transmission facility not subject to the PSB's

siting authority. The Environmental Board is comprised of

nine persons appointed by the governor with the senate's

consent. The Board chairman serves for a two year term and

the remaining eight members are appointed to four year terms.

Some of the administrative functions in connection with the

Board's responsibilities are handled.by District Environmental

Commissions. There are nine such commissions, serving nine geographic districts. The commissions consist of three

members from the district appointed by the governor.

Neither the PSB or the Environmental Board have a totally preemptive role in siting energy facilities in Vermont. A facility's operating characteristics or design may require separate approvals from other state and local agencies. 


\section{SCOPE OF SITING JURISDICTION}

The PSB's siting jurisdiction is derived from Title 30, Section 248 of the Vermont Statutes. Section 248 prohibits any "conamy" or cooperative from beginning site preparation for on construction of an elcctric generation or transmission facility unless the PSB certifies that the project will promote "the general good of the state." Section 248 applies to electric generation or transmission facilities of any size. The only exception to the statute is for the replacement of existing facilities with equivalent facilities in the usual course of business. "Company" is the only term in Section 248 which is separately defined, and means: ". . individuals, partnerships, associations, corporations and municipalities, owning or conducting any public service business or property used in connection therewith, other than railroads and aircraft... .

The Environmental Board exercises siting jurisdiction conferred upon the Board by a state land use law, popularly referred to as Act 250 (of 1969). I' Act 250 requires that a permit be obtained for any subdivision or development. The definition of "subdivision" is not relevant to the siting of energy facilities. The term "development," however, covers energy facilities not covered by Section 248 and is defined to mean :

the construction of improvements on a tract 
or tracts of land, owned or controlled by a person, involving more than 10 acres of land within a radius of five miles of any point on any involved land, for commercial or industrial purposes. "Development" shall also mean the construction of improvements for commercial or industrial purposes on more than one acre of land within a municipality which has not adopted permanent zoning and subdivision bylaws.... The word "development" also means the construction of improvements on a tract of lari snvolving more than 10 acres which is to be used for municipal or state purposes. In computing the amount of land involved, land shall be included which is incident to the use such as lawns, parking areas, roadways, leaching fields and accessory buildings. The word "development" shall not include an electric generation or transmission facility which requires a certificate of public good under section 248 of Title 30 . The word "development" shall also mean the construction of improvements for commercial, industrial or residential use above the elevation of 2,500 feet. $8 /$

The permit requirement in Act 250 applies to individuals, corporations, associations, trusts, any other legal or commercial entities, state agencies and municipalities. 9 / with respect to utility facilities, Act 250 applies only to facilities not covered under section 248, which will occupy a minimum number of acres. The Environmental Board exercises its siting jurisdiction over any facilities not subject to the PSB's jurisdiction including storage, consumption and carrying facilities; and over non-electric utility facilities.

Both the PSB and the Environmental Board have promulgated rules and regulations, which are contained in the Vermont Administrative Procedures Compilation. The regulations of the PSB do not further define its siting jurisdiction. Environmental Board Rule $2(8 / 1 / 71)$ exempts from 
the Board's jurisdiction construction commenced before August 31, 1970. The Environmental Board Rules and Regulations

further specify the types of electric transmission and generation facilities which are exempt, or which may be excepted from the Board's jurisdiction:

b) Exceptions:

(i) a generation or transmissiun facility which requires a reptificate of public good under 30 V.S.A. chapter $b$, section 248 ...

(ii) in an emergency situation requiring immediate action such as, to protect the health or safety of the public.. .

(iii) situations requiring the temporary installation of transmission facilities...

(c) Exemptions:

(i) a transmission facility within a development or subdivision having a permit from a district environmental commission; or

(ii) an under or on ground transmission facility helow the elevation of $2,500^{\prime}$, rccocdcd and or reforested provided it is not located in a natural area, scenic area, or scenic corridor, as defined in 10 V.S.A. section 1309; or

(iii) an under or on ground transmission facility within a right-of-way, ijeluding a publio highway, existing, cleared, and in use, as of the effective date of these rules or having a permit under 10 V.S.A. chapter 151 provided that such installation will not require widening or changing the character of lise existing right-of=way or as may be specified in a permit; or

(iv) an above ground transmission facility in a right-of-way existing, cleared, and in use, as of the effective date of these rules, excepting rights-of-way for public highways, where such installation does not require widening or changing of the character of the right-of-way; 
or

(v) an above ground transmission facility to be located on existing, and in use, transmission facilities.

(d) All utilities undertaking the development of a transmissior. Eacility considered exempt under subsection (c) above will notify in writing the District Envicomental Commission in which the majority of the Eacility yill lie of said development. II'

The Environmental Boarā is reviewing its administrative regulations, and a spokesman for the Board indicated that revised regulations might expand the Environmental Board's exercise of jurisaiction over utility facilities.

The siting authority of the PSB ard the Environmental

Board is not preemptive of the authority of other state agencies. The departments which make up the Environmental Conservation Agency such as the Water Resource Department, exercise a wide range of powers relating to natural resources and conservation. $\stackrel{13 /}{ }$ A permit under Act 250 does "not supercede or replace the requirements for a permit of any other state agency or municipal government." $\frac{14 /}{4}$ There are no provisions allowing the Board to override local zoning requirements for any facilities covered by Act 250, and the Environmental Board expressly requires that permits from state or local agencies be obtained prior to the issuance of a permit under Act 250.15 However, local zoning provisions are merely advisory in regard to the section 248 siting process; if a Section 248 permit is secured, there is no need to comply with local zoning regulations. $16 /$ see part IV below, for a 
discussion of other state and local agencies.

III. CERTIFICATION PROCESS

A. Procedural Requirements to be Satisfied by the spplicant

A party seeking a certificate of public good under SEニṫo: 249 must file a petition with the PSB. The petition must be supplemented by copies of all testimony and exhibits the petitioner believes necessary to support a grant of its application. $17 /$ The statute is otherwise silent as to the form and contents of such a petition.

An applicant for a permit under Act 250 must file with the appropriate District Environmental Commission copies of a plan of the proposed development, $\stackrel{18 /}{ }$ and notice and a copy of the application to the municipality, and municipal and regional planning commissions having jurisdiction over the subject land.

B. Procedural Obligations of the siting Agency Upon receipt of a petition for a certificate under Section 248, the PSB must hold a public hearing in the county in which the facility is proposed to be located. The hearing is not required to be held within any specified time. Notice of the hearing is to be given by the PSB to the state Attorney General, the Department of Health, Environmental Conservation Agency, Historic Sites Board, Scenery Preservation Council, State Planning Office, Vermont Aeronautics Board and by certified mail to the director of the municipal and regional planning commissions and municipal legislative bodies for each town and 
city in which the proposed facility will be located. Such notice of the public hearing must be given not less than 30 days prior to the hearing. Notice is also to be published in a "newspaper of general circulation" in the county or counties in which the proposed facility will be located, for two weeks successively, the last publication to be $a=1$ lest 12 days before the hearing. $19 /$

With respect to applications under Act 250 , upon receipt of an application, a District Environmental Commission is to forward notice and a copy of the application to the Environmental Board, any state agency directly affected, and any other state agency or municipality deemed appropriate. Notice must also be published in a local newspaper where the land is located not more than seven days after receipt of the application. 20./

Within forty days after the receipt of an application under Act 250 , a hearing must be held by either the Environmental Board or District Commission. Parties to the hearing must be given at least 10 days notice of the hearing. The Environmental Board or District Commission must issue findings and conclusions within twenty days following the final hearing. 2 / Act 250 and the Environmental Board Rules do not require the Board or District Commissions to consult formally with other state or federal agencies.

\section{Appeal of Agency Decisions}

\section{Public Service Board}

The rehearing and appeal procedures for a decision 
made under section 248 are the same as those for other PSB decisions. These procedures are itscussed in Section $V$ of Chapter 2 .

\section{Enviromental Boara}

An appeal fron a decision by a District Commission

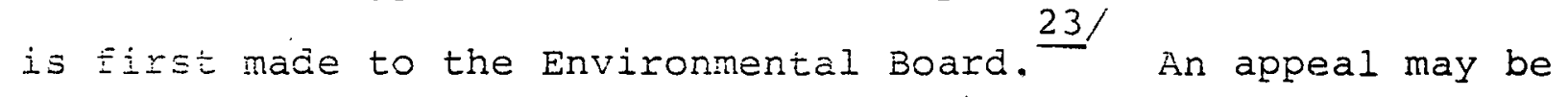
removed by the applicant to the superior court of the county in which any real estate of the applicant involved in the application is Located. $\frac{24 /}{}$ The Board or superior court holds a de novo hearing on all findings requested by any party. In the case of an appeal to the Board a hearing must be held within forty days of the notice of appeal. An appeal from a decision of the Board or superior court can be made only to the supreme court of Vermont. The supreme court may not consider objections which were not raised in the lower proceedings, and the findings of the Board or superior court with respect to questions of fact are held to be conclusive. 25/ IV. CERTIFICATION STANDARDS

The electric facility siting statute, section 248 , sets out four criteria for the issuance of a permit. Before the PSB issues a permit, it must find that the proposed construction:

(1) will not unduly interfere with the orderly development of the region, with due consideration having been given to the recommendations of the municipal and regional planning commissions and the municipal legislative bodies; 
(2) is required to meet the need for present and future demand for service;

(3) will not adversely aifect system stability and reliability and economic Fators; and

(4) will not have an undue adverse effect on esthetics, historic sites, air and water purity, the natural environment and the public health and safety $26 /$

of the four factors used in evaluating a petition the PSB piaces special emphasis on protecting the scenic and environmental values of the state. $27 /$ section 248 does not provide guidelines or criteria for evaiuating compliance with the folir Eactors.

\section{Under Act 250 the Environmentai Board and District} Commissions must make ten findings of fact before issuing a permit for a development. The following aspects of the development are to be considered: potential for air and water pollution; availability of sufficient water for the project; burden on existing water supply; potential for soil erosion or reduction in the capacity of the land to hold water; potential for causing unreasonable congestion or unsafe conditions with respect to the use of transportation facilities; burden on the ability of a municipality to provide educational and governmental services; effect on the scenic and natural beauty of the area, historic sites, and irreplaceable natural areas; conformity with the state capability and development plan; and conformity with any duly adopted local or regional plan or capital program. 
Act 250 establishes specific criteria for evaluating a project's impact on air and water pollution and its conformity with the "state capability and development plan." $\stackrel{29 /}{ }$ The state capability and development plan was formulated to encourage uniform policies on land use and development in the state. The plan deals with environment, natural resources, recreation, ristorical areas, and with public ntilities. The plan is a general declaration of legislative intent, and does not prohibit or restrict any specific types of development.

The permit criteria in Section 248 and in Act 250 apoly to all facilities or developments subject to their respective jurisdictional provisions. Any recommendations and reports received from other agencies are advisory with respect to such permits and there are no standards to be followed by the PSB or Environmental Board in overriding the negative recommendation of another agency. However, all other required state permits must be obtained as a pre-requisite to obtaining permits under either section 248 or Act 250 . As a practical matter then, state agencies with permitting authority have veto power over the decisions made by the PSB or Environmental Board.

The rules and regulations of the two siting boards do not provide additional standards for evaluating applications for siting permits.

V. LOCATION AND PLANNING OF DEVELOPMENTS GENERALLY

Because permits are required from other state agencies 
even for facilities subject to the provisions of Act 250 and Section 248 , and because local restrictions apply to facilities subject to Act 250 , those separate approvals are noted in this Part.

A. Environmental Conservation Agency

The ECA was formed in 1970 by the consolidation of several existing state agencies. Three of the departments of the Environmental Conservation Agency (ECA) require permits for construction. The Department of Water Resources requires a permit of any person who wishes to discharge any waste, substance or material into any waters of the state. Prohibited discharges include those which cause certain levels of thermal pollution. $\stackrel{30 /}{ }$ certain waters of the state are classified as "high-quality," and any proposed discharges into such waters must receive "the highest practical degree of treatment currently available."

The Water Resources Board, which is part of the Department of water Resources, requires a permit of any person who proposes to construct a structure upon the bed of any lake or pond which is a public or boundary water of the state $\frac{32 /}{\text { The }}$ Water Resources Board will issue a construction permit upon a finding that the construction will serve the public good and not adversely affect the environment.

The air quality section of the ECA may require a permit prior tollthe construction or installation of particular types of air contaminant sources. ${ }^{34 /}$ The statute makes the 
permitting procedure an optional control measure, as opposed to the mandatory air quality standards administered by the Agency .

\section{B. Planning Authorities}

The Vermont Planning and Development Act of 1967 authorized municipalities to form municipal, joint and regional planning commissions. $35 /$ The plans prepared by these commissions may be adopted verbatim or with modifications by a municipality as zoning regulations. $\frac{36 /}{}$ zoning regulations may impose typical restrictions, e.g. on building height, density, impervious cover. No provisions deal specifically with public utilities or energy facilities. As noted earlier, local development plans must be followed in the Act 250 permitting process, but not in issuing a Section 248 certificate. 


\section{FOOTNOTES}

1. Vt. Stat, Änn, ¿i亡. 30, $\$ 243$ (Equity Supp. 1980).

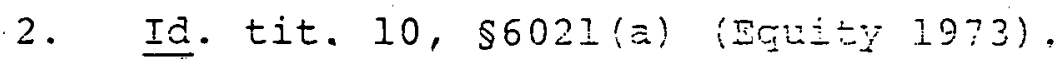

3. Id. tit, 10, $\$ 6026$ (a) (Equity Supp, 1980).

4. Id. \$6026(b) (Equity 1973).

5. See Part II and part IV of this Chapter.

6. Vt. Stat. Ann. tit. 30, \$201 (Equity Supp. 1980).

7. Id. tit. 10, \$6001 et seq. (Equity 1973; Equity Supp. 1980).

8. Id. \$600I (emphasis added) (Equity Supp. 1980).

9. I3. 56001 (14).

10. Mr. G, Gianninoto, Evnironmental Board, Telephone conversation, $7 / 21 / 78$.

11. Environmental Board Rules Annotated, $A-3$ (b) (c), (d) (1971).

12. Mr. G. Gianninoto, Environmental Board, Telephone conversation, 7/21/78.

13. See Vt. Stat. Ann. tit. 3, \$2803 (Equity 1972),

14. Id. tit. $10 \$ 6082$ (Equity 1973).

15. Environmental Board Rules and Regs., 13(c).

16. City of South Burlington $v$. Vermont Elec. Power Co., Co., Inc., 133 Vt. 438,344 A.2d 19 (1975) (The defendant proposed to construct a $115 \mathrm{KV}$ electric transmission line and substation, located largely in South Burlington. The facility was certificated under title 30 of the Vermont statutes $\$ 248$, but the City refused to issue a zoning permit.

17. Public Service Board, Rules and Regs., 3 (f).

18. Vt. Stat. Ann. tit. 10, \$6083 (Equity 1973).

19. Id. tit. $30, \$ 248$ (a) (Equity Supp. 1980).

20. Id. tit. 10, \$6084 (Equity 1973).

21. Id. $\$ 6085(a)$. 
22. Environmental Bcard Rules Annotated, R.15 (1976).

23. Vt. Stat. Ann, tit. 10, \$6089(a) (Equity Supp. 1980).

24. Iivid.

25. Id. $\$ 6089(a)(c)$.

26. Id, tit. $30, \$ 248(\mathrm{~b})$.

27. Mr. G. Tarrant, Special Counsel, PSB, Telephone conversation, 7/20/78.

28. Vt. Stat. Ann. titl 10,\$6086. (Equity Supp. 1980).

29. Id. $\$ 6042$ (Equity 1973); See Vt. Stat. Ann. tit. 10, $\overline{\$ 6085(1), ~(9) ~(E q u i t y ~ 1980) . ~}$

30. Vt. Water Pollution Control Permit Regs, 13.2, 18 (1974).

31. Regs. Governing Water Classification and Control of Quality, Rule 3, (1974).

32. Vt. Stat. Ann. tit. 29, \$404 (Equity 1970).

33. Id. $\$ 405$ (Equity Supp. 1980).

34. Vt. Stat, Ann, tit. 10, $\$ 556$.

35. Id. tit. 24, $\$ 4301$ et seq. (Equity 1975).

36. Id. $\$ \$ 4401$ (Equity Supp. 1980), 4405 (Equity 1975). 


\section{CHAPTER 4 \\ FRANCHISING OF PUBLIC UTIIITIES IN VERMONT}

Neither the vermont Constitution nor the state statutes expressly grant local governments the authority to issue franchises or licenses to use streets or other public property. Municipalities are created by state legislative action granting a charter. This charter enumerates the powers which may be exercised by the municipality. Although the powers granted a municipality in its state charter may vary from town to town, the state legislature does have the power to grant franchising authority to municipalities in their charters.

To determine the procedure applicable to granting a franchise or the criteria to be considered, one must examine individual municipal charters and ordinances enacted pursuant to those charters. For example, in the one reported decision which discussed franchising procedures, the city ordinance provided that a party seeking a franchise must apply to the city council. Notice of the application was to be published in a local paper within seven days of receipt of the application. The permit would be granted at the next regular meeting of the council if no objections were received. $\frac{2 /}{\text { No }}$ reported decisions have discussed the criteria to be considered in granting a franchise. 
The characteristics of a franchise also have been left to the aiscretion of the state legislature in granting a charter and the local government in enacting ordinances pursuant to its charter authority. Judicial and administrative opinions offer little guidance in identifying the characteristics of a franchise. The vermont supreme court has held, however, that a franchise grant does not give the recipient the exclusive use of any street or public property; although a franchisee must be allowed to exercise his franchise free from interference. $\underline{3} /$

However, local franchising law currently is largely insignificant with respect to public utilities. Public utilities are certificated by the vermont Public Service Board (see discussion in Chapter 2, section IV) and the Vermont Supreme court has held, in City of South Burlington v. Vermont Electric Power Co.,$\underline{4}$ that a holder of a certificate need not obtain local approval before constructing facilities. This case dealt specifically with a municipality's attempt to require that a certificated public utility obtain a local zoning permit. However, the principle stated In the case, that state licensing of public utilities must prevail over local licensing, would appear to be applicable to the situation in which a local government attempts to prevent a certificated utility from operating without a local franchise. According to a representative of the Vermont 
Attorney General, public utilities are not locally franchised in Vermont and a public utility need only obtain a certificate from the Public Service Board before commencing operations or constructing facilities. 至 


\section{FOOTNOTES}

1. Rutiand Cable T. . Inc. V. City of Rutland, 121 Vt. 399, 159 a $2083(1960) ;$ City of Bane $\mathrm{v}$. Perry \& Schribner. 82 vt. 30173 A. 574 (1909).

2. Rutland Cable T.V:, Inc. V. City of Rutland, 121 Vt. 399, 159 A.2583(1960).

3. Rutlana Elec. Ifiht Co. V: Marble Elec. Light Co., 65 Vt. 377, 26. A. 635.(1893).

4. City of S. Burlington V. Vermont Elec. Power C๑., 133 Vt. $438, .344$ A, 2d 19 (1975).

5. Mr. T. Viall, Assistant Attorney General, Telephone conversation, $7 / 21 / 78$. 
CHAPTER 5

\section{RATE REGULATION IN VERMONT}

\section{RATEMAKING AUTHORITY}

A. General

The Public Service Board of Vermont ("PSB") has authority to determine the reasonableness of the rates of any company subject to its jurisdiction and may, after hearing, make adjustments to a company's rates as it finds just and reasonable. $1 /$ "Company" is defined as including individuals, partnerships, associations, corporations, electric cooperatives, and municipalities conducting any public service business, other than railroads and aircraft. $2 /$ According to this definition of "company" which expressly includes cooperatives and is broad enough to include investor-owned and publiclyowned utilities, all three types of utilities are subject to rate regulation by the $\mathrm{PSB}$. Although the statutes grant certain powers to municipalities in regard to gas and electric utilities, the statutes do not confer authority on municipalities to approve or prescribe rates of utilities.

The PSB has authority to prescribe the forms of all books, accounts, papers and records of any public utility, other than railroads, over which it has jurisdiction 4 While every public utility is required to keep its books, accounts, papers and records accurately and faithfully in the manner and 
form prescribed by the PSB, public utilities under the jurisdiction of a federal agency are not required to keep any system of accounts and records which would conflict with any requirement of such federal agency.

Vermont has adopted the National Association of kegulatory Utility Commissioners ("NARUC") system of accounts for gas utilities. (Prnpane gas companico uze NaRUC. One natural gas company was recentiy allowed to change to the Federal Energy Regulatory Commission ("FERC") system of accounts.) Electric utilities use the FERC system of accounts. The Vermont Statutes contain no provisions prescribing or approving depreciation rates or procedures.

\section{B. Procedures}

Each company is required to file rate schedules with the PSB which are tó be open to public inspection. A rate change may not be made in any schedule, except upon fortyfive (45) days' notice to the PSB and to the Department of Public Service and such notice to affected parties as the PSB shall direct. All changes should be plainly indicated upon existing schedules or by filing new schedules forty-five (45) days prior to the time the changes are to take effect. However, upon application of any company, and with the consent of the Department of Public Service, the PSB may prescribe a shorter time within which such change may occur. If a change involves a rate decrease, such rate change may be made upon five (5) days' notice to the PSB and affected parties. 
At least six (6) days before the date on which such new or changed rates are to become effective, the PSB, on its own motion or upon the motion of any five persons adverseiy affected by the change, may order an investigation and hearing on the justress and reasonableness of such change. If the rate change adversely affects less than five persons, any one person so affected may apply to the PSB by petition alleging the unreasonableness of such rate.

If the PSB orders that a change may not take effect until final determination of the investigation and hearing, it must proceed to hear the matter as promptly as possible and make its determination within six (6) months from the date that the change otherwise would have taken effect. If the PSB fails to make a determination within a six (6) month period, the company may put a changed rate into effect upon filing with the PSB a bond running to the board members and their successors in office.

\section{8/}

If the PSB makes its decision within six (6) months, its final order will be retroactive to the day that the proceedings were instituted, and its order will contain a directive that the utility repay to the persons from whom collected "between the time proceedings were instituted and the final order ali sums in excess of the rates ultimately found to be just and reasonable." $9 /$ If the PSB does not make its determination within six (6) months, the final decision will contain a directive that the utility refund only the excess collected between six (6) months after the institution of the proceedings 
and the date of the final determination.

When, upon hearing, the rates are found to be unjust, unreasonable, insufficient or unjustly discriminatory; the PSB may order and substitute such rates as it deems to be just and reasonable. $\stackrel{11 /}{ }$ Beyond a general mandate that rates allowed to public utilities should be reasonable and nondiscriminatory, the statutes do not contain any provisions governing the disposition of particular issues in a rate case.

\section{RATE BASE DETERMINATION}

\section{A. Test Period}

Ordinarily the PSB uses an historical average teet pcriod fur valuing rate base on the grounds that this method recoqnizes asset. growth, inorcases in accumulated depreciation and properly matches income with assets. $\stackrel{12 /}{\text { In }}$

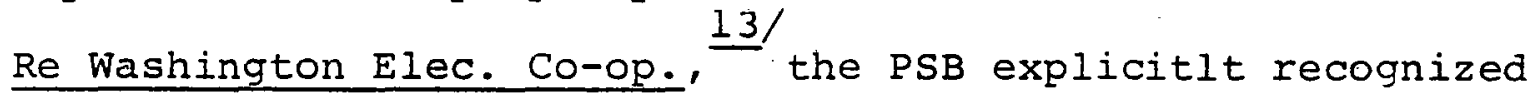
its traditional preference for an average rate base:

Ordinarily, the board uses the average rate base in setting rates because it is usually a good standard for estimating future investment. The average rate base anticipates and makes allowances for the offsetting factors of asset growth and increases in accumulated depreciation, and has the further advantage of matching properly the flow of income in a given year with any change in the amount of plant assets. 14/

Nonetheless, the PSB approved the use of year-end figures because the company had experienced a high rate of investment 
in plant and equipment (it was predicted that by 1980 , investment would be double the amount in 1971). The PSP acknowledged that the addition in utility plant would generate increased revenues, but concluded that the growth in revenues would probably not keep pace with the sharp rise in investment. $\underline{15 /}$

B. Rate Base Valuation

The PSB uses original cost less depreciation to determine the value of a utility's rate base. $\stackrel{16 /}{\text { original }}$ cost is defined as the "cost incurred by the utility in purchasing the facility, not the original cost of a prior owner. $17 /$ Thus, where a utility realized a good bargain in purchasing certain facilities for $\$ 411,119$ less than their net book worth, the PSB held that the company's rate base should reflect only the actual purchase price paid by the utility. $\underline{18 /}$

c. Rate Base Components and Adjustments

Where a utility engages in a "non-utility" business, in addition to providing regulated service, the PSB has held that rate base should reflect only that portion of plant attributable to the provision of regulated utility service. Thus, in a gas utility rate case where a utility conducted both a regulated gas distribution business and a non-regulated gas appliance and bottled gas business, the PSB adjusted certain items of plant common to both businesses to reflect only that part of the value of those revenues attributable 
to the provision of regulated utility service. $19 /$ similarly, in Re Green Mountain Power Coro.' $\frac{20}{}$ the FSB heid that merchandising activities are not necessary to the provision of atility seryice and excluded the compon's investment in rental waterheaters from its rate base. However. in Re

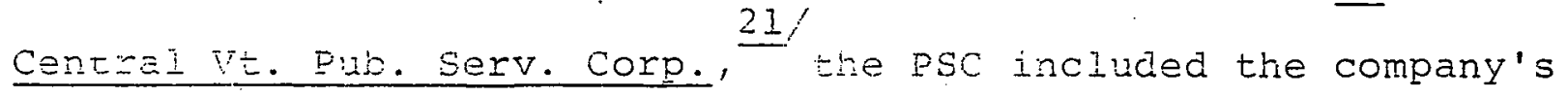
investment in rental waterheating units because the units were timed so as not to contribute to peak use and therefnre had a desirabie effect upon the tight power supply situation.

Historically, the PSB has excluded construction work in progress (CWIP) due to construction of major plant facilities from rate base, holding that:

Capitalizing interest is the preferred method of treating costs incident to such facilities because the alternative method of including substantial sums in the rate base for facilities not yet operating unfairly force present customers to pay for facilities to be used by future customers, 22/

The PSB has included CWIP for minor facilities constructed over a short period of time where interest is not charged during construction. $23 /$ More recently, in a telephone company rate case, the PSB has stated that a utility. "should capitalize no interest on construction work in progress, should therefore add no interest income to its revenues, but is entitled to the benefit of all its construction work in progress rate base. This comports with the law of Vermont and is the most just and reasonable method for petitioner and ratepayers." 
Most recently, in the PSB's first major rate case since undergoing a change in composition, the board took the position that inclusion of CWIP in rate base should be limited to items of utility property the use of which will commence soon after the test year. $\stackrel{25 /}{ }$ Thus, the PSB excluded the company's investment in five out-of-state nuclear plants because the company had little control over when such plants might go on line and their history of construction delays indicated that their completion time was indefinite.

The PSB did allow Central Vermont to include CWIP in rate base for facilities which were "due to serve customers shortly after the test year." $\frac{27 /}{}$ In addition, the PSB held. that an offset against revenue requirements of AFUDC was unnecessary, recognizing that such a practice "which results in earnings which are not cash, . . could well weaken the company in the Einancial marketplace."

The PSB has dealt with the proper treatment of "property held for future use." The PSB recognizes that "utilities must acquire land well in advance of intended use." $29 /$ In determining whether "property held for future use" qualifies for rate base inclusion, the PSB considers "the length of time property will be held before it is dedicated to service and whether it was prudent as a matter of business judgment to make the purchase at all." 2 The PSB included New England Telephone's "property held for 
future use," without further explanation. However, in

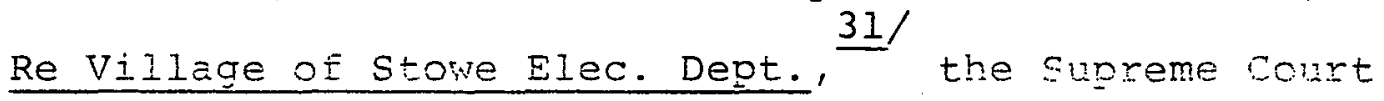
of Vermont held the PSB in error for including property in a utility's rate base, which had been purchased Eive years prior to the case with no further steps having been taken to put it into use (i.e. failure to purchase a right of way). $32 /$ In one of its most recent decisions, the PSB included only that portion of the vollually's property held for future use for which the company had specific development plans. $33 /$

D. Allocation of Rate Base According to a PSB Utility Rate Accountant, there are no utilities in Vermont which provide two or more utility services from a single farility. $\frac{34 /}{}$ Thcrcfore, the psB has not dealt with the issue of rate base allocation between two ulility operations provided from a single facility. However, in Re Green Mountain Power Corp., $\underline{35 /}$ the PSB approved the company's use of a peak responsibility method to assign rate base between jurisdictional retail and nonjurisdictional wholesale customers, noting that it was the method adopted in a prior PSB order. $\underline{36 /}$

In $\mathrm{Re}$ Capital City Gas, Inc., $\stackrel{37 /}{ }$ the PSB considered the allocation of rate base between a utility's regulated and non-regulated activities. For eight months of the test year, the company conducted both a regulated business 
(distribution of gas through pipelines) and a non-regulated bustiess (sales of bottiea gas and the sale and rental of gas applicances). Both the PSB staff and the company allocated certain items of rate base (as well as expense) using the percentages of total sales attributable to the utility's regulated and non-regulated business and the PSB approved.

III. COST OF SERVICE

A. Allowable Expenses

The general test for inclusion of expenses in the cost of service appears to be reasonableness of the actual costs incurred in the rendition of utility service. Actual test year expenses may be adjusted for subsequent known changes and nonrecurring expenses are eliminated or normalized.

The PSB has held that "reasonable charitable contributions of a regulated utility should be allowed," reasoning that utility companies "should be encouraged to become responsible members of their communities and to be sensitive to the needs of those communities. The PSB also allowed "reasonable" membership dues, because in its view, ratepayers as a whole benefit from such membership in the long run. $40 /$ However, in a subsequent gas utility case, the PSB excluded dues for the president of the 
company to local businessmen's and civic organizations Decause they were unrelated to the provision of utility service. 4I/

The PSB generally allows reasonable advertising expenses in the cost of service but has disallowed certain promotiona advertising because it is not in the public interest. The PSB nae diso aisalluwed advertising expenses incurred for the sale and rental of gas appliances and bottled gas (non-regulated activities) concluding that "the cost of advertising non-utility business shoula not be attributed to the ntility as in expense to be botre by the utility ratepayers." $13 /$ In Central vermont Pubiic service Corporation's most recent request for a rate increase, the PSB allowed the cost of advertising expenses less an amount attributable to the promotion of nuclear power.

The PSB has found that lobbying expenses are unfust and unreasonable and disallows them for ratemaking purposes on the grounds that "any needs that the petitioner has in the legislature should be directed to his board, which was designated by the legislature to protect the public's interest in this area."

The PSB has indicated its approval of the inclusion of research and development expenses in the cost of service. The PSB allowed one company to include an expenditure which represented a contribution to the Electric Power Research Institute with this comment: 
It is hard to imagine how an industry can improve upon its technological base without research and development expenditures. To an extent the lack of such expenditures by the industry has led to near total. dependence upon the government and power equipment suppliers for innovation and improvement, a policy we feel to have greater potential for harm to ratepayers in the long run than the adjustment here sought. $\underline{46 /}$

\section{B. Allocation of Joint Expenses}

In the only reported case in which the PSB

explicitly ruled upon the allocation of joint expenses, the PSB approved of the allocation of expenses to utility and nonutility operations using the percentages of total sales attributable to each operation.

C. Allocation of Costs Between Customer Classifications In Re Burlington Elec. Light Dept., $\frac{48 /}{}$ an electric company employed the average and excess demand method of allocating costs for providing electricity between various customer classes. The PSB approved of the company's method of allocation noting that it produced "similar results to the peak responsibility method normally employed by the board."

IV. FEDERAL INCOME TAX ISSUE

A. Liberalized Depreciation

In a recent telephone utility rate case, the PSB stated that as it would "hereafter treat deferred taxes 
I as a zero cost component of the company's capital structure, deferred taxes related to accelerated depreciation should not be ceducted from rate base." $\stackrel{50 /}{ }$ In a more recent rate decision, in which central Vermont Puilic Service Corporation sought a rate increase, the PSB flowed through liberalized depreciation.

\section{B. Inveslment Tax credits}

The PSB's treatment of investment tax credits has recently undergone what appears to be a dramatic change in policy. In a 1974 case, an electric company concluded that it was appropriate to flow through the benefits of the investment tax credit and the PSB held that unused credits should also be flowed through. 2 Two years later, the PSB held that the benefits of the investment tax credits under both revenue acts should not be flowed through immediately but flowed through over the life of the assets, on the grounds that the tax benefits should be shared by ratepayers who use the plant over its useful life and that normalization would augment the company's cash flow and thereby lower its cost of capital. ${ }^{53 /}$ More recently, the PSB approved Central Vermont Public Service Corporation's method for calculating the amount of investment tax credit because the method recognized the shift in treatment "which may well be in the long term interests of the ratepayers." In this case, the company flowed-through the amount of its investment tax credit for 1976 and 1977, but amortized the 
amount of its credit for 1978, over the lives of the assets.

7. METHODS USED FOR DETERMINING THE RETURI TO BE ALLOWED A REGULATED UTILITY

\section{A. Determination of Return on Equity \\ The PSB does not lise a particuiar method or} combination of methods to set a return on equity. Rather, it considers the determination "largely judgmental and not susceptible to precise calculations." $\frac{55 /}{}$ The PSB récognizes the usefulness of analytical tools such as market to book ratios and interest coverages, but maintains that "their use must be tempered by what is actually occurring in the market place. . which is the best indicator of investor expectations and views about the financial integrity of a company." $56 /$ "The record provides neither an answer nor a choice of answers, but a source of factual considerations and expert judgments from which to derive our own conclusions." In its emphasis upon "what is actually occurring in the marketplace," the PSB has attached special significance to comparable earnings studies. Thus, in a utility case, the PSB adjusted the witness-recommended return on equity upward, noting that a telephone company "in some measure has to compete with electric utilities for investment dollars and that comparisons between the growth rates of these respective utilities are useful." ${ }^{58 /}$ In Re Central 
Vt. Pub. Serv. Corp. ${ }^{59 \prime}$ the PSB found that a broad historic view of returns on common stock is the correct analysis when moderated by careful stuci of more recent periods and in particular conditions such as the rate of inflation, erosion of earnings and He clearly unsatisfactory standing of a company.'s securities in the market. In Re Capital City Gas Co., Inc., $\frac{50 /}{\text { the }}$ PSB set a rate of return on equity which was based on a comparable earnings study, without explanation.

In short, in determining a company's return on equity, tha pSE uses expert studies mereiy as guidelines, although it apparently placed particular emphasis on evidence of the earnings of comparable companies. This approach gives PSB the flexibility to account for other factors in arriving at a return on equity. Those factors have included: the impact of the PSB's order (i.e., an allowance of a fuel adjustment clause or the denial of an attrition allowance); and a company's poor financial rating by Moody's or Standard and Poor. $61 /$

B. Overall Return and Return on Equity Allowed The table in Appendix A lists the overall return and the return on equity which have been allowed in recent rate cases. There are no reported decisions wherein the PSB has explicitly made allowances in the authorized rate of return to provide an incentive or to impose a penalty on a company. 
Only one decision has dealt with the issue of the application of double leverage in determining the cost of equity. In Re New England Tel. \& Tel. Co.,, the PSB held that the use of the theory of double leverage is unreasonable where the subsidiary company is not wholly owned by its parent because "such treatment does not accurately reflect the petitioner's cost of capital." The PSB conceded that a "more persuasive case" for the use of double leverage might have been made, had the utility been wholly owned by its parent.

VI. RATE DESIGN CRITERIA

Reported PSB decisions indicate that it is appropriate to consider factors other than cost in setting rates although cost-of-service is apparently the central approach to setting rates to various customer classes. In Re Vermont Gas Systems, the PSB was confronted with the issue of whether the proposed rate increase should apply to the utility's interruptible customers, as well as its firm customers, despite the fact that the cost of service studies indicated that the interruptible customers were already paying their proportionate share of the costs. The public witness maintained that the interruptibles should not be exempt from the rate increase because they wre not paying for the value of their service, in that their rates 
did not reflect the fact that the cost of gas was substantially lower than the cost of the interruptibles' alternative fuel source. The PSB agreed that once customer cost responsibilities have been established, it is appropriate to consider value of service:
Establishing a fair and reasonable rate structure cannot be limited solely to on analysis of incremental costs and rates of return. The concepts of "reasonableness" and "justneos" require us to recognize social and economic factors and to give them proper consideration in fixing rates. This can be called the "value of service" theory of rate design, whereby rates are adjusted to reflect the relative benefits enjoyed by the various classes of customers. $66 /$

However, the PSB held that the interruptible customers should be exempt from the rate increase. Two factors contributed to the PSB resision. Firct, the PBB puinted out that the value of service determination had to include $a$ weighing of the benetits realized by the firm customers from the interruptibles, which were substantial (i.e., the interruptibles provided diversity of load; enabling the utility to meet its take or pay obligations under its supply contract). Secondly, the public witness was unable to provide the specific cost differences betwecn gas and the alternative sources of fuel. However, the PSB ordered the utility to file specific information with the PSB, concerning the relative crimpetitive prices of fuels, so that the PSB could more accurately determine whether the interruptible customers were paying their "value of service." 
In a more recent case, the PSB noted that a telephone utility traditionally set rates on the basis of value of service. Evidently, the PSB had summarily dismissed a previous case brought by the utility because of its failure to divulge customer cost responsibilities. However, the PSB noted that it

did not intend to set all individual rates based solely on cost, but rather needs this information to help guide it in determining whether rates are just and reasonable. The board is well aware of the imprecision of cost studies, and to use incremental costs as a first or source study, would only add a second element of imprecision.67/

In setting the utility's rates, the PSB did not permit any deviations from cost (other than to hold that the elderly and handicapped should not be charged for directory assistance), essentially because the utility failed to provide any justification for the proposed deviations.

Lifeline rates are not statutorily mandated. However, it should be noted that the PSB has been extensively involved in the area of electric rate reform.

In late 1974, the PSB entered into an agreement with the Federal Energy Administration (FEA) which provided a $\$ 360,000$ grant and selected Green Mountain Power to study six "non-traditional rate forms for electric utilities" .... As a by-product of the FEA study, an off peak rate plan was made available to al1 GMP customers in June 1976 and to date has been adopted by approximately 190 customers. Also included in the FEA grant, and still continuing, is the study of 'Ripple Control' and heat storage systems. 
Currently GMP has 300 customers under its Ripple Experiment; whereby control signals activate heating elements in hot water heaters and turn them off in periods of peak demind ... . Also under test are 15 ceramic and 1 hot water heat storage units which utilize off-peak energy to balance load characteristics. Success today has prompted GMP to promote these units for new home heating units and to repiace older existing units.68/

In Re Central Vt. Pub. Serv. Corp.,$\frac{69 /}{}$ the PSE approved of the implementation of seasonal rates, as well as time-of-day rates for residential and general service customers on an experimental basis. Apparently, central Vermont is utilizing other load management techniques, such as a Ripple control system and heat storage system. $10 /$. There are no reported decisions wherein the PSB has discussed either the resale pricing of excess energy or the pricing of by-product services resulting from electrical or thermal generation.

VII. ISSUANCE OF SECURITIES

The PSB is granted the authority to control the issuance of securities. $\stackrel{71 /}{ }$ The PSB has jurisdiction to hear and determine all matters respecting the issue of stock, mortgages, bonds or other securities. A domestic corporation subject to the jurisdiction of the PSB may not issue any stocks, bonds, notes or other evidences of indebtedness without the consent of the PSB.

$$
\underline{72 /}
$$


The statutes provide that no issue of stocks or bonds will be made that is inconsistent with the public good. I3/ In pe vermont Yankee Nuclear Power Corp. $\frac{74 /}{\text { the }}$ PSB interpeted the "public good" to include public health and safety. In an earlier decision, the PSB declined to aporove issuance of securities where there was no evidence that the proposed additional financing was warranted on considerations of safety.

In 1971, the "public good" was again the standard which the PSB applied in determining whether to approve the issie of securities. In Re Vermont Yankee Nuclear Power Corp.' the PSB held that although the financial situation of companies sponsoring a nuclear power company was not totaliy certain, a certificate of consent was granted to a power company to issue and sell bonds, since the elimination of " all risk would necessitate higher rates for electricity, which would not be consistent with the public good.

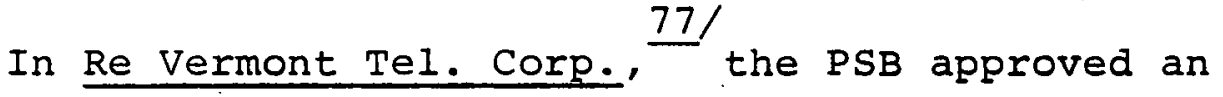
issue of securities where it was found that an improvement in service and minor economies would be affected.

The PSB has considered the propriety of particular capital structures in-determining whether to authorize the issuance of securities. Thus, it has authorized the issuance of securities where the capital structure of a company would 
be beneficially affected.

The PSB also takes capital structure into account in rate cases making adjustments to actual capital structures when different capital structures are deemed more appropriate. For example, in a case in which an electric cooperative's capitalization consisted of 94.26 per cent long-term debt and 5.74 per cent member's equity, the PSR found that a proper capital atructure fur determining a fair rate of return for the cooperative would be composed of 70 per cent debt and 30 per cent equity and the overall allowed rate of return was adjusted to reflect such a capital structure.

When an electric utility was found to be relying too heavily on high cost short term borrowings, the PSB made an adjustment to the test year actual capital structure and determined a proper return based on a capital structurc which assumed the issuance of certain long term deht: and preferred stock to reduce the amount of short term debt. The utility was admonished to "make every effort to roturn Lo a more normal capital structure of approximately $50 \%$. per cent long-term debt, 15 per cent preferred stock and 35 per cent equity." 
APPENDIX A

\begin{tabular}{|c|c|c|}
\hline CASE & $\begin{array}{l}\text { ALLOWED } \\
\text { OVERALL }\end{array}$ & $\begin{array}{l}\text { ATE OF RETURN } \\
\text { ON } \\
\text { COMMON EQUTTY }\end{array}$ \\
\hline $\begin{array}{l}\frac{\text { Re Central Vt. Fu. Serv. Corp. }}{\text { Docket No. } 4320(1978)} \\
7 \text { P.U.R. } 4 \text { th } 67(1974) \\
\frac{\text { Re Capital City Gas Co., Inc. }}{27 \text { P.U.R.4th } 361(1978)} \\
\frac{\text { Re New England Tel. \& Tel. Co. }}{13 \text { P.U.R.4th } 268(1976)} \\
\frac{\text { Re Green Mountain Power Corp. }}{\text { Docket No. } 4036 \text { (1975) }}\end{array}$ & $\begin{array}{c}10.6 \\
9.5 \\
10.33 \\
9.4 \\
9.77\end{array}$ & $\begin{array}{l}14.5 \\
14.5 \\
15.0\end{array}$ \\
\hline
\end{tabular}


FOOTNOTES

1. Vt. Stat. Ann. tit. 30, $\$ 218$ (Equity 1970).

2. Id. $\$ 201$ (Equity Supp. 1980),

3. Id. \$2902 (Equity 1975).

4. Id. $\$ 221$.

5. Id. $\$ 222$.

6. Id. $\$ 225$ (Equity Supp, 1980).

7. Id. $\$ 226$ (c) (Equity Supp. 1980).

8. Id. $\$ 227$ (a) (Equity 1970) .

9. Id. $\$ 227(\mathrm{~b})$.

10. Ibid.

11. Id. $\$ 218$

12. Re Central Vt. Pub. Serv. Corp., 89 P.U.R.3d 121 (1971).

13. 1 P.U.R. 4th 47 (1973).

14. Id. at 51 .

15. Id. at 51 .

16. Ke Vermont Gas Systems, Inc., 100 P.U.R.4th 202 (1973).

17. Id. at 209 .

18. Id. at 209 .

19. Re Capital City Gas Co., Inc., 27 P.U.R.4th 361 (1978).

20. 94 P.U.R.3d 417 (1972).

21. 89 P.U.R.3d 121 (1971).

22. Re Centrai: Vt.: Pub. Serv. Corp., 89 P.U.R.3d 121, 126 (1971).

23. Green Mountain Power Corp., 94 P.U.R.3d 417, at $421-$ 422 (1972).

24. Re New England Tel. \& Tel. Co., 13 P.U.R.4th 268, 272(1976).

25. Re Central Vt. Pub. Serv. Corp., 28 P.U.R.4th 469,476 (1978). 
26. Id. at 473 .

27. Id. at 475 .

28. Id. at 476 .

29. Re New England Tel. \& Tel. Co., 13 P.U.R.4th 268, 273 (1976).

30. Id. at 273 .

31. 134 Vt. 559, 367 A2d. 1056 (1976).

32. Id. at 1060 .

33. Re Central Vt. Pub. Serv. Corp., 28 P.U.R.4th 469 , 479 (1978).

34. Mr. Ray Colliander, Utility Rate Accountant, PSB, telephone conversation $7 / 13 / 79$.

35. 94 P.U.R.3d 417 (1972).

36. Id. at 424 .

37. 27 P.U.R.4th 361 (1978).

38. Burlington Elec. Light Dept., 95 P.U.R.3d 273, 275-276 (1972); Green Mountain Power Corp., supra note 23, at 425 .

39. Re New England Tel. \& Tel. Co., 13 P.U.R.4th 268, 276 (1976).

40. Id. at 876 .

41. Re Capital City Gas Co., Inc., 27 P.U.R.4th 361, 364 (1978).

42. Re New England Te1. \& Te1. Co., 13 P.U.R.4th 268, 275-276 (1976).

43. Re Capital City Gas Co., Inc., 27 P.U.R.4th 361 (1978).

44. Re Central Vt. Pub. Serv. Corp., 28 P.U.R.4th 469, 481 (1978).

45. Re New England Tel.\& Tel. Co., 13 P.U.R.4th 268, 276 (1976).

46. Re Central Vt. Pub. Serv. Corp., 7 P.U.R.4th 67, 74 (1974).

47. Re Capital City Gas Co., 27 P.U.R.4th 361 (1978). 
48. 95 D.U.R.3C $273(1972)$.

49. Id. at 27?.

50. New Encland Tel. and Tel, Eo., 13 P.U.R.4th 268,272 $(1976)$.

51. Mr. Ray Colliander, Utility Rate Accountant, PSB, TelEphone conversation, T/18/79.

52. Fe Central Vt. Fub. Sery. Corp., 7 F,U.R,4th 67 (1974).

53. Re New England Tel.\& Te1, Co., 13 P.U,R.4th 268, 271 (1976).

54. Re Central Vt. Pub. Serv. Corp., 28 P.U.R.4th 469,481 $(1978)$.

55. New England Tel. s Iei. Ce., 13 P.U.R,4th 268, 274 (1976).

56. Id. at 274 .

57. Re Central Vt. Pub. Serv. Corp., 7 P.U.R.4th 67,78 (1974).

58. New England Tel, \& Tel. Co., 13 P.U.R.4th 268, 274 $(1976)$.

59. 7 F.U.R.4th $67(1974)$.

60. 27 P.U.R.4th 362, (1978).

61. See Re Central Vt. Pub. Serv. Corp., 7 P.U.R.4th 67 ,

62. 13 P.U.R.4th 268 (1976).

63. Id. at 275 .

64. Mr. Ray Colliander, Utility Rate Accountant, PSB, Telephone conversation, 7/18/79.

65. 100 P.U.R.3d 202 (1973).

66. Id. at 217 .

67. Re New England Tel.\& Tel. Co., 13 P.U.R.4th 268, 278 (1976).

68. Argus Utility Scope Regulatory Service, August 1978 , pp. $8=9$. 
69. 7 P.U.R.4th (1974).

70. Argus Utility Scope Regulatory Service, August, 1978, pg. 9 .

71. Vt. Stat. Ann, tit. 30, $\$ 209$ (a) (7) (Equity Supp. 1980).

72. Id. $\$ 108(a)$.

73. Ibid.

74. 86 P.U.R.3d 337 (1970).

75. Re Vt. Yankee Nuclear Power Corp., 72 P.U.R.3d 273 (1968).

76. 91 P.U.R.3d 1 (1971).

77. 71 P.U.R.3d 267 (1967).

78. Re Cent. Vt. Pub. Serv. Corp., 71 P.U.R.3d 455 (1967).

79. Re Washington Elec. Co-op. Inc., 1 P.U.R.4th 47 (1973).

80. Re Central Vt. Pub. Serv. Corp., 7 P.U.R.4th 67,81 (1974). 


\section{CHAPTER 6}

\section{SUMMARY OF IMPEDIMENTS TO TMPTEMENTATION OF ICES}

\section{Types of Impediments}

In order to analyze the extent to which the traditional public utility regulatory system may impede the implementation of ICES, one must first ident.ify what is meant by the word "impediment." For the purposes of this analysis, four broad types of impediments can be identified. The first major category of impediment is the "no-subsidy impediment." This impediment consists of the failure of the government or the regula- tory system to provide some desired degree nf monetary or other encouragement of ICES. Such subsidies could take the form of grants or tax incentives. On the other hand, a subsidy could result from state public utility regulatory commission (PUC) departure from strictly cost-based rates for purchases and sales of electricity between an ICES and conventional electric utilities, thereby compeling the customers of the electric utility grid to subsidize ICES.

The second major category of impediment is the "uncertainty impediment." The absence of certainty with respect to the manner in which an ICES will be regulated will impose costs that must be borne by the ICES operator. Uncertainty impediments will appear in many forms. ICES will be faced with uncertainty because it represents a new concept which can be 
expected to raise issues with which utility regulators are unfamiliar. Such uncertainties will be aggravated as a result of the fact that regulatory jurisdiction in the United. States is decentralized. Thus, these uncertainties will inave to be resolved largely on a jurisdiction-by-jlisisciction basis. In addition, ICES will necessarily be involved in the sale of excess electrical power to and the purchase of back-up electrical power from conventional electric,utilities. These arrangements, however, can be altered by a PUC even though the ICES and utility initially. agreed upon the terms. Therefore, ICES will face transactional uncertainties not normally encountered in doing business outside the utility field.

Another major category of impediment is the "discriminatory impediment." This type of impediment takes the form of rules or regulations which, for whatever reasons, affect ICES more harshly than competing energy technologies. These diferences in impact may be the result of any number of factors including, but not limited to, ICES size, the type of customers it can be expected to serve and the manner in which it will do business.

The final general category of impediment is the "prohibition impediment." These impediments could be either regulations which impose so substantial a cost on the ICES that it cannot operate economically or regulations which would actually preclude operation of an ICES. 
II. Regulatory Impediments to ICES impiementation

The degree and manner in which the existing regulatory system will impede the derelocment of ICES will vary depending on the form of owersin, cisss of customer and

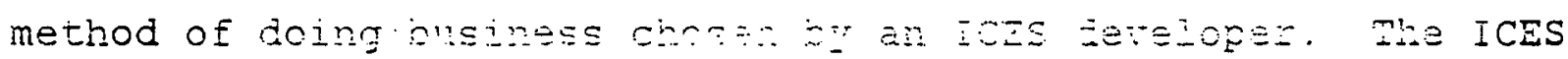
type which can be expected to encounter the most sericus impediments is the investor-owned ICES seeking to construct a new facility to serve customers in a community already being served by a conventional utility. such an ICES will face impodimento in the form of general PUC regulation, regulations relating to the siting of facilities and the granting of local franchise and regulations concerning rates charged for energy service.

\section{A. General Regulatory Impediments}

Public utility regulation probably is more pervasive and complex than any other form of government regulation of business. A businessman not engaged in the utility business may be reluctant to become involved in a business which will subject him to such pervasive governmental regulation. Some examples of areas of regulation which might discourage investors from becoming involved in ICES implementation are the requirement that a regulated utility maintain its books in conformity with a system of accounts prescribed by the EUC and PUC regulation and scrutiny of the financial affairs of the utility. When the ICES is operated in conjunction with a non-utility business, such regulation necessarily will extend beyond the operator's utility operations and involve PUC examination of 
its non-utility business. Attempts at minimizing the effects of these types of impediments by setting up a subsidiary corporation to own and operate the ICES could subject the parent company to jytensive Securities and Exchange Commission regula-

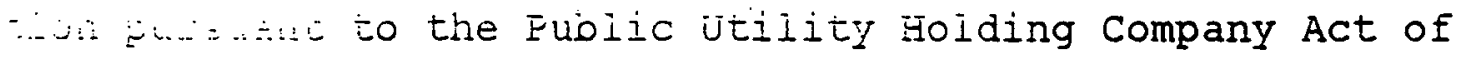
1933.

Even if an ICES developer is willing to face the possibility of extensive PUC regulation, it will face a significant uncertainty in determining whether it will be deemed a public utility and therefore subject to PUC regulation. All states require that a utility provide service "to or for the public" before it becomes subject to the jurisdiction of the PUC. Few states, however, have provided any real guidance with respect to the meaning of the phrase "to or for the public." Thus, an ICES operator can expect very little guidance in determining whether its operations will be sufficient to bring it within the classification of "public utility."

Similarly, many states require that a utility "sell" utility service before it will be classified as a public utility. Again, statutes, administrative rules and caselaw provide very little guidance with respect to when a transaction will be classified as a "sale." Thus, the ICES operator must face another significant area of uncertainty with respect to PUC regulation of its operations.

Assuming that some aspects of the ICES operations will bring it within the classification of public utility, a 
serious question remains with respect to whether sales of both of the ICES energy streams will be subject to PUC regulation and, if not, whether and by whom the non-PUC regulated energy stream will be regulated. This uncertainty arises because many sたミたอ statutury sこhemes provide for the regulation of only certain enumerated utility services such as heat, electricity and gas. In such states, the provisions of refrigeration or motive power may not be within PUC jurisdiction. Regardess of whether these energy streams will be regulated by local governments, or left unregulated, such split regulation may raise significant problems with respect to the marketing of both energy streams at competitive rates.

state territorial assignment programs could present an impediment capable of precluding operation by ICES. Several states have enacted legislation which specifically provides that the PUC is to divide the state into a finite number of service areas and assign each of these service areas exclusively to a particular utility. Where such programs exist, service area assignments have been made and, generally, these programs make no provision for the assignment of service areas to new utilities unless there is some indication that customers are not being adequately served. Even where no specific statutory allocation scheme exists, PUCs generally have sought in granting certificates of public convenience and necessity to avoid what they viewed as wasteful duplication of facilities by granting the first utility serving a given area in effect an exclusive 
right to serve that area so long as the utility provides adequate service. Thus, in many cases, an ICES may find that it is precluded from initiating operations as a result of these territorial assignment programs.

\section{B. Siting Imoediments}

The siting of energy production facilities is regulated in some manner in all states. The types and degree of impediments presented will vary depending on the type of siting program in effect in a particular jurisdiction and the type of facility proposed to be constructed. In those states which have not adopted comprehensive one-stop siting programs, a utility desiring to construct an energy production facility generally must seek approval from a variety of state and local agencies. Because an ICES developer in such a state will be forced to obtain numerous approvals, the procedural requirements related to obtaining such multiple approvals could present significant impediments to the implementation of ICES. In those states which have attempted to minimize the procedural difficulties presented by the need to obtain multiple approvals by implementing one-stop comprehensive siting programs, an ICES operator may face significant impediments in the form of substantive requirements in obtaining the required approval.

c. Local Eranchising Impediments

In addition to obtaining certificates of convenience and necessity from PUCs and siting approvals from one or more state agencies, ICES operators generally will be required to 
obtain franchises from local governments to use public rightsof-way for transmission and distribution facilities. Because of the total lack of uniformity in the $i a \%$ anc procedures governing local franchising, iCES operators will face many uncertainties in this area. One major uncentainty related to whether a franchise is needed or available and, if a franchise is not available, whether this will noride the use of public rights-of-way in conjunction with the operation of the ICES. Many-franchise enabling statutes list specific services which local governments are authorized to franchise. In addition, most statutes require that the franchisee be serving a public purpose in order to be eligible for a franchise. These types of restrictions raise the question of whether, if an ICES is providing a service which is not deemed to be serving a public purpose, a franchise may be granted. If a franchise cannot be granted, significant uncertainty exists with respect to whether the ICES may operate along public rights-of-way without a franchise. If not, it may be precluded from operating unless all facilities are maintained on private property with the permission of the property owners.

Assuming a franchise is available tọ an ICES, additional uncertainty exists with respect to the procedure pursuant to which the franchise will be granted and the standards which will be applied in determining whether the franchise should be granted. These procedures and standards vary substantially from state to state and from municipality to municipality within each state. 
Finally, an ICES which might otherwise be eligible for a franchise may be unable to obtain the necessary franchise as a rasult of a prior grant of an exclusive franchise to another utility serving the area. Nearly one-half of the states have not resolved the issue of whether exclusive franchises are permissible.

D. Rate Regulation Impediments

Assuming that an ICES operator can overcome or operate in spite of the impediments described above and begin its operations, it must be able to market both energy streams at competitive rates in order to stay in business. Several areas of PUC rate regulation may impede the ICES' ability to operate profitably. For example, an ICES may find that the rates for one energy stream are regulated on a statewide basis by the PUC while the remaining stream is regulated by one or more local governments. With such split jurisdiction, there can be little assurance that rates will be regulated consistently and in such a way as to enable competitive marketing of both energy streams. Even if both energy streams are regulated by the PUC, resolution of various cost and rate-base allocation issues could present serious issues unique to ICES. Depending on the method chosen to allocate costs and rate base between the two services being marketed, the ICES operator may find that it will be compelled to sell one energy stream at a rate too low for the whole ICES to be profitable while the second energy stream must be sold at a rate too high to be competitive. 
In addition, PUCs traditionally have exercised ratemaking authority only with respect to sales by conventional utilities operating in a monopoly market. Investment in these conventional utilities traditionally has been considered a low-risk investment and, therefore, the rates of return on equity permitted by PUCs have been commensurately low. Because ICES, as a new industry and as a utility operating in competition with other utilities, will be viewed as a more risky investment, PUC decisions with respect to allowable rates $n f$ return will have a significant impact on the ability of ICES to attract investors. Rates of return satisfactory to investors in conventional utilities are unlikely to attract investors to the more risky ICES operations.

Finally, ICES must be able to obtain reasonable rates for sales of excess electrical power to and purchases of back-up electrical power from conventional electric utilities. These. rates also will be regulated by PUCs and the PUC determinations will substantially affect the ability of the ICES to operate profitably. The uncertainty surrounding the factors that will be considered by PUCs in establishing these rates is very likely to be perceived as an impediment by prospective ICES operators and investors. 


\section{CHAPTER 7}

\section{OVERCOMING IMPEDIMENTS TO ICES -- SUMMARY}

The Chapter 6 analysis demonstrates that the traditional public utility regulatory system presents numerous impediments to the implementation of ICES. These impediments do not appear in the form of a list of individual statutory or rule provisions which can be easily modified to accommodate ICES. Rather, the impediments take the form of the existing regulatory system itself -- a system which is based largely on a set of assumptions and practices foreign to the ICES concept.

Because the existing regulatory system is, in effect, the major impediment to the implementation of ICES, there are only two available alternatives for dealing with this impediment. Advocates of ICES can attempt to change, the system, or they can work within the system in order to demonstrate the value of the ICES concept. Because many of the regulatory provisions which appear to be impediments to the implementation of ICES are integral parts of the existing regulatory system, however, any effort to change the system sufficiently to encourage the widespread implementation of ICES will require changes so fundamental that traditional forces operating within the system would have little trouble blocking such changes. Thus, a widespread effort by the advocates of ICES to change the system may result in a substantial expenditure of resources while bringing about very little change. 
There is no single configuration or form of ICES. While differences can result from employing different technologies to produce different energy streams, the most useful classifications for purposes of analyzing potential institutional impediments to the implementation of ICES are those based on type of owner/developer and the nature of the customer group served. The classification scheme used in the following analyses includes ICES-Utility -- an ICES owned and operated by a conventional electric utility, ICES-Complex -- an ICES designed to serve existing institutional complexes such as government, commercial, industrial, residential or medical centers, ICESHeat Plant -- an ICES providing thermal service for its own use or the use of a limited class of customers and selling all electrical output to a conventional utility, ICES-Co-Op -- an ICES owned by its customers and serving only these member/customers and ICES-Entrepeneur -- an ICES owned and operated by any entity intending to sell or provide utility service at retail to all users within a particular service area. Obviously, additional types, of ICES can be developed by combining these various modes of ownership with the various available customer classes.

ICES may be established gradually in forms that will not encounter, or not be significantly affected by, many of the impediments discussed above. When the various types of ICES are compared against the existing regulatory framework, it is apparent that there is a wide range in the degree of compatibility 
between that framework and the various ICES types. The degree to which the implementation of ICES will be impeded by the existing regulatory system varies greatly depending on the form of ownership of the ICES, the number and type of customers which it intends to serve and the manner in which it will conduct its utility perations. Therefore, if advocates of ICES seek implementation along the paths of least resistance, this gradual implementation will provide ICES technology with an opportunity to establish its viability and adapt to the existing regulatory system while permitting the existing system to become familiar with and adapt to the peculiar problems and benefits of ICES. The following may be the most appropriate sequence of implementation of ICES.

\section{ICES-UtiIity}

ICES-Utility would include any ICES owned by an existing electric utility and operated as a part of its existing utility business. The utility could either operate its own cogeneration equipment or operate equipment owned by another entity on behalf of the owner. The utility would carry on its electrical operations in the same manner as it had before becoming involved with the ICES, but the particular arrangements for the sale of thermal energy could vary. Thermal energy might be distributed by the ICES-Utility to individual customers or it could be sold in bulk to a single customer for use by that customer or for further distribution by it. 
ICES-Utility, because it would be operated by an existing utility, would be least affected by the regulatory impediments discussed in Chapter 6. As an existing utility, the ICES operator would aiready be subject to pUC reguiatory jurisdiction and would have the experience necessary to function within that system with a minimum of inconvenience. in addition, the ICES-Utility might se able to install and maintain its ICES equipment pursuant to existing franchises, certificates or other approvals or obtain minor modifications in these prior approvals so as to permit the ICES operations.

\section{I . ICES-Complex, ICES-Heat Plant}

A second approach would be to structure ICES so as to take advantage of traditional exemptions built into the existing regulatory scheme in most states. In all states, a utility must be providing service "to or for the public" before it will be subject to PUC regulatory jurisdiction. In about half of the states, a utility will be subject to PUC jurisdiction only if it is deemed to be making "sales" of energy service. If the

ICES is structured so as to either not be deemed to be providing service "to or for the public" or not to be making "sales" of energy services, that ICES would not be subject to PUC regulatory jurisdiction. ICES-Complex and ICES-Heat Plant would be structured so that energy services would be provided only to a limited and clearly defined class of customers. In addition, in many cases, such ICES may be able to provide energy service 
as a part of an over-all rental package rather than on an individual metered basis. Such ICES could, in many cases, avoid classification as public utilities. Examples of such ICES would be an ICES established to serve a residential, industrial, commercial, governmental or university compiex.

A great deal of uncertainty exists with respect to what types of service can be provided and to how many customers before a utility will be deemed to be subject to PUC jurisdiction. These uncertainties, however, could be remedied by means of fairly simple legislative or administrative action.

By operating so as to avoid PUC regulatory jurisdiction, these ICES will also give up the protections afforded by the regulatory system. Thus, such ICES may be able to operate in competition with conventional utilities without having to obtain PUC approval, but they also must be capable of waging a competitive battle with the existing utilities in the area to be served because they would not enjoy the Iuxury of the traditional monopoly status of a public utility. similarly, such ICES would not be subject to PUC rate regulation but would also possibly not receive adequate regulatory protection in their attempts to negotiate contracts to purchase back-up power from or sell surplus power to conventional utilities.

\section{I . ICES-CO-OP}

ICES-CO-Op, unlike the ICES discussed above, could lend itself to broad implementation of ICES. By operating as a 
cooperative -- a utiiity which is owned by its customers and provides service only to these owner/customers -- the ICES-CO-Op colid avoid many of the nore troublescme aspects of the traditional regulatory system while stili enjoying many of its benefits. For examoie, utility cooperatives are exempted from zuc rate regulation and regulation of financial affairs in many states. On the other hand, uilility cooperatives often are subject to service area restrictions and, therefore, are afforded the protections of the various methods of territorial allocations utilized by puCs.

This traditional utility concept could be utilized by, and modified to better serve, ICES projects intended to serve large numbers of customers. One area of possible modification would be to permit qualifying ICES-Co-Ops to commence operations in service areas of conventional utilities under certain circumstances. Qualifying ICES-Co-Ops could be allowed to serve only large concentrations of new customers or they could be allowed to serve existing concentrations of customers. The prejudicial effect of such an extension of the cooperative concept could be minimized by requiring ICES-Co-Ops to purchase those facilities of the conventional utility within the ICES service area which are necessary for serving the ICES customers and which would be rendered unnecessary to the utility. 
IV. Exempt-ICES

By utilizing the ICES types discussed above, advocates of iCES can impiement ICES in forms which will be least affected by regulatory impeitinents in order to establish showcase ICES designed to demonstrate the viability and special benefits of the ICES concept. After these showcase ICES have existed in peacerui coexistence with conventional utilities for a time, conventional utilities, utility regulators and legisiators may be more amenable to the tipe of system modifications necessary to encourage widespread implementation of ICES in maný forms. At this point, the advocates of an ICES might EFectiveI petition PUCs and state iegislatures to define ... certain categories of ICES which will be exempt from certain.: troublesome aspects of the traditional regulatory system while enjoying some of its benefits.

In order to qualify as an Exempt-ICES, the ICES must, of course, be required to establish that it would be a reliable, responsible supplier of energy. Once utility regulators are convinced that the ICES has the financial and technological ability to adequately serve its proposed customers, the ICES could be exempted from many traditional areas of regulation without jeopardizing the best interest of the customers.

The Exempt-ICES should be permitted to commence operations to appropriate groups of customers in the service areas of conventional utilities. However, like the ICES-CO-Op, it should be required to purchase any equipment owned by the conventional utility which is rendered useless as a result of 
the ICES being permitted to serve customers within the conventional, utility's service area. Once it has established its service area, the Exempt-ICES should receive the type of territorial protection traditionally afforded public utilities.

The Exempt-ICES could also be freed from traditionai PUC rate regulation. Rather than establishing traditional cost-based rates, the Exempt-ICES could be permitted to market its energy package at any rate which does not exceed the rates for comparable service from conventional utilities. If the Exemot-ICES believed that it was, for some reason, entitled to higher rates, it should be compelled to submit to traditional rate-making procedures. This should assure that, if the ICES concept is in fact economicaliy viable, investors will be able to achieve sufficient returns on their investment while ICES customers are guaranteed reliable energy service at reasonable rates. 